\title{
"A prison with extra flavours": experiences of immigrants in Swedish immigration detention centres
}

\author{
Soorej Jose Puthoopparambil, Beth Maina Ahlberg and Magdalena Bjerneld
}

\author{
Soorej Jose Puthoopparambil \\ is a PhD Candidate at the \\ Department of Women's and \\ Children's Health, University \\ Hospital, Uppsala University, \\ Uppsala, Sweden. \\ Beth Maina Ahlberg is Adjunct \\ Professor at the Department of \\ Women's and Children's \\ Health, University Hospital, \\ Uppsala University, Uppsala, \\ Sweden and Head of Research \\ at Skaraborg Institute for \\ Research and Development, \\ Skövde, Sweden. \\ Magdalena Bjerneld is a \\ Researcher at the Department of \\ Women's and Children's Health, \\ University Hospital, Uppsala \\ University, Uppsala, Sweden.
}

\begin{abstract}
Purpose - The immigration detention environment largely influences the health and well-being of detainees by either aggravating medical conditions or contributing to new illness. There is limited research on how detainees experience and try to cope with this environment. The purpose of this paper is to describe experiences of detainees in Swedish immigration detention centres.

Design/methodology/approach - Semi-structured interviews were conducted in three detention centres with a total of 21 detainees who had been detained for at least two weeks. Interview transcripts were analysed using thematic analysis.

Findings - The detainees likened immigration detention to imprisonment. They experienced lack of control over their life situation mainly through arbitrary restrictions and lack of proper response from authorities making it appear futile to seek help. This perceived lack of control forced them into passivity. Differences in amenities provided in the centres were observed and some of these were reported to assist in making detention more bearable.

Research limitations/implications - This study provides only one stakeholder perspective. The perspectives of other stakeholders, such as detention staff, health care professionals and volunteers must be explored to improve understanding and mitigate the effects of detention.

Originality/value - Irrespective of the better standards of detention in Sweden, the detainees considered detention as imprisonment affecting their health and well-being. If states deem detention to be necessary, improved staff-detainee interaction should be ensured through proper staff training, arbitrary restrictions within detention should be avoided and health care services should be improved.
\end{abstract}

Keywords Sweden, Health and well-being, Immigration detention, Irregular migrants, Sense of control Paper type Research paper

\section{Introduction}

Immigration detention plays a pivotal role in efforts made by the European Union (EU), its member states and other national governments around the world in facilitating the deportation of irregular migrants (Fekete, 2005; Steel et al., 2011; Coffey et al., 2010). The International Organization for Migration (IOM) (2011) defines detention as restriction on freedom of movement through confinement that is ordered by an administrative or judicial authority. According to various national and international guidelines immigration detention should be used as a last resort. It is an administrative step taken to prevent an immigrant from not cooperating with the deportation process, to enforce a deportation order, to verify identity documents, to protect public health through medical screening and treatment of communicable diseases, and for national security (UNHCR, 2012; Swedish Migration Board, 2006; IOM, 2011; Ministry of Justice, 2005). Governments have been increasing their detention capacities and critics argue that detention is increasingly not used as a last resort, 
but rather as a systematic way to detain and deport irregular migrants (Fazel and Silove, 2006; Broeders, 2010; Leerkes and Broeders, 2010; Mendonça, 2010; Silverman and Massa, 2012; Malloch and Stanley, 2005; Steel et al., 2011).

Efforts are made by international and non-governmental organizations (NGOs) to stop the detention or make it more humane. As a result, the detention of children has been stopped or reduced in some countries and there has been an increased focus on pursuing alternatives to detention (Fazel and Silove, 2006; Sampson et al., 2011). However, detention continues to be enforced.

Previous studies have shown higher rates of physical and mental health problems among detainees which are often created or aggravated by their detention (Coffey et al., 2010; Fazel and Silove, 2006; Hollings et al., 2012; Keller et al., 2003; Klein and Williams, 2012; Robjant et al., 2009; Steel et al., 2011; PHR and The Bellevue/NYU Program for Survivors of Torture, 2003; Venters et al., 2009). Negative health effects may last even after detainees are released from detention (Klein and Williams, 2012; Silverman and Massa, 2012; Coffey et al., 2010).

Studies have also focused on human rights, political and historical aspects of immigration detention (Malloch and Stanley, 2005; Leerkes and Broeders, 2010; Fekete, 2005; Broeders, 2010; Venters et al., 2009) and how detention has affected detainees' lives in general (Klein and Williams, 2012; Coffey et al., 2010; Khosravi, 2009; Pourgourides, 1997).

One of the minimum standards for detention put forward by several international organizations is that the detaining authority has to safeguard the health and well-being of detainees (Mendonça, 2010; IOM, 2011; UNHCR, 2012). However, there is limited research on how individuals adapt to the detention environment or on how to ensure their proper health and well-being (Hollings et al., 2012; Venters et al., 2009; Coffey et al., 2010). A deeper understanding of the daily life of detainees and the environment they live in is required in order to mitigate the effect of detention on the health and well-being of detainees.

One of the most widely used definitions of health, a state of complete physical, mental and social well-being and not merely the absence of disease or infirmity (WHO, 1946), has come under criticism, mainly because it is considered to be all inclusive, unattainable and unrealistic (Awofeso, 2005; Huber et al., 2011; Saracci, 1997; Callahan, 1973). Scholars argue that the inclusion of the word "complete" makes it impossible for individuals to be healthy for a longer period of time. However, so far no one has been able to come up with a more accurate definition of health (Awofeso, 2005; Callahan, 1973). It might be unrealistic to aim for "complete" health or well-being for individuals in confinement, and we have therefore chosen the Ottawa Charter for Health Promotion's description of health which emphasizes changing or coping with a given environment for creation of health.

The Ottawa Charter for Health Promotion (WHO, 1986) states:

Health is created by caring for oneself and others, by being able to take decisions and have control over one's life circumstances, and by ensuring that the society one lives in creates conditions that allow the attainment of health by all its members. To reach a state of complete physical mental and social wellbeing, an individual or group must be able to identify and to realize aspirations, to satisfy needs, and to change or cope with the environment.

\section{Immigration detention in Sweden}

Sweden is a major recipient of asylum claims in the world (UNHCR, 2014), but in 2012, around two-thirds of the asylum applications were rejected (Swedish Migration Board, 2013). The majority of the detainees in Sweden are asylum seekers who have been denied asylum in Sweden (Khosravi, 2009). Immigration detention is regulated by the Aliens Act (Ministry of Justice, 2005). The Swedish Migration Board (SMB), the Migration Court, the Migration Court of Appeal or the police can take the decision to detain an individual in any of the five detention centres around the country with the capacity to detain a total of 255 individuals (Swedish Migration Board, 2014). The SMB is responsible for running the detention centres and usually manages detention cases. However, if an individual absconds or if the SMB deems it necessary to use force to carry out deportation, the case is handed over to the police who use the SMB's detention facilities to 
accommodate the detainee while making arrangements for his/her deportation. The maximum duration of detention for adults is 12 months. Children can be detained for a maximum of 72 hours which can be extended to 144 hours under exceptional circumstances. Detention centres have special sections for female detainees where male detainees are not allowed. The SMB has a responsibility to ensure special arrangements are made when detaining families. According to SMB's (2014) annual report, the total number of detainees in 2013 was 2,864 of which 11 per cent were women.

Detainees share sleeping rooms with two to five people and have common toilets and showers. Detention centres have recreational facilities such as a library, television and limited access to courtyard. Security at the centres is maintained by locked doors, high walls surrounding courtyards and staff carrying a communication device allowing them to contact their colleagues or other emergency services.

The staff at the detention centres are not security personnel and do not wear uniforms, in contrast to some western countries (Silove et al., 2007; Hall, 2010; Venters et al., 2009). They are responsible for detention case management, and the daily management and security of the detention centres. They have varied ethnic and educational backgrounds.

Detainees do not wear uniforms. They receive three main meals a day and a daily allowance of 24 Swedish kronor. Mobile phones without cameras are allowed or detainees are provided with one. They have continuous internet access depending on computer availability. They can receive visits from family and friends. Volunteers from NGOs visit detainees and can help them with their spiritual, social and practical needs.

The county council in which the detention centre is located has the responsibility for providing health care services to the detainees. Health conditions which cannot be deferred (emergencies) should be attended to (Sections 3 and 6, Ministry of Justice, 2008). They also have the right to maternity care, abortion and contraceptive advice. All detention centres, except one, have a nurse visiting the centres once or twice a week. One detention centre has a nurse visiting five days a week. If deemed necessary by the nurse, a detainee can be referred to a doctor or a counsellor. Staff also refer detainees to health centres (Swedish Migration Board (SMB), 2012).

\section{Sense of control}

To further explain the experiences of the detainees, the concept of sense of control (Skinner, 1996) was found to be relevant.

A detention system is established to control the presence of irregular migrants in a country (Broeders, 2010; Khosravi, 2009). Consequently, migrants are detained and eventually deported. One has a lower sense of control during confinement (Goodstein et al., 1984; Woodall et al., 2014). As stated in the Ottawa Charter for Health Promotion (WHO, 1986), sense of control has a huge influence on an individual's health and well-being. Although there are different theoretical constructs of control, such as locus of control, personal mastery and learned helplessness (Skinner, 1996; Krause and Stryker, 1984; Abramson et al., 1978), it has been shown that a general high sense of control, a core aspect of various constructs of control, is a strong predictor of high levels of well-being and health and better coping strategies (Krause and Stryker, 1984; Seeman and Seeman, 1983; Lachman and Weaver, 1998; Wallston et al., 1987; Woodall et al., 2014).

Three main aspects of control are actual control, perceived control and experienced control (Skinner, 1996). Theorists believe that perceived control is a better indicator of functioning than actual control as a personal conviction that control exists is enough to trigger an action independent of the actual presence of control (Skinner, 1996; Goodstein et al., 1984). Experienced control is the control experienced by an individual while trying to create a desired outcome (Skinner, 1996).

It is thus the lack of control over their lives for detainees, and its implications for their health, that is the concern of this paper. 
Aim

The study aimed to explore and describe the perceptions and experiences of immigrant detainees in Swedish immigration detention centres. The study is part of a larger project aimed at identifying relevant factors that could mitigate the harmful effects of detention on the health and well-being of detainees.

\section{Methodology}

In 2010, the first author (hereafter referred to as the researcher) conducted a pilot study on detainee experiences at one of the Swedish detention centres. This centre is not part of the present study. Results from the pilot study were discussed with the SMB and national NGOs, which led to the initiation of the project. A reference group consisting of members from three national NGOs acts as a forum where practical implications of the project results are continuously discussed.

A qualitative research design using semi-structured interviews was adopted for the study. Permission to conduct interviews at the detention centres was sought through e-mails sent to the five detention centres in the country. The first three centres to respond were chosen for data collection. Information about the study and an invitation to participate was displayed on the notice boards in the detention centres two weeks prior to the interviews.

\section{Study participants}

A total of 22 detainees (19 men, three women) who met the inclusion criterion, being detained for at least two weeks, were interviewed. Their ages ranged from 18 to 57 years. There was one couple among the participants and they were interviewed together. Participants expressed willingness to participate through the staff, or directly to the researcher while visiting the centres, or participants who were present in the common areas of the centres, such as the dining room or recreational rooms, were invited by the researcher to participate. Of the eight female detainees who met the inclusion criteria, two could not participate because an interpreter was not available at the time and three declined without giving any reasons. Female detainees were offered the opportunity to be interviewed by a woman. One male detainee who declined said he was afraid his participation might affect his case if the staff came to know about it. The rest did not provide any reason for declining to participate. The participants were from Belarus, Chile, Guinea, Iraq, Morocco, Nicaragua, Palestine, Senegal, Serbia, Sierra Leone, Uganda and the USA. Their duration of detention ranged from two weeks to nine months.

\section{Ethical considerations}

Ethical approval for the study was obtained from the Regional Ethical Review Board, Uppsala, Sweden.

Prior to the interviews, details about the study such as contact person, aim, confidentiality and the voluntary nature of participation were explained verbally and through a written information sheet. Participants were informed that their participation would not influence their case. Verbal consent was obtained from all the participants.

\section{Data collection}

Interviews were conducted in Swedish or English by the researcher during February to April 2012. Each detention centre was visited by the researcher continuously for a week or more for conducting interviews. Field notes were written based on observations and interactions with the staff.

The interview guide, used during the pilot study, was modified for the present study. The questions were divided into four main parts, including; background information such as country of origin and duration of detention; detainees' perceptions about the care provided at the detention centres; and interaction with the staff, volunteers and fellow detainees. Interviews were conducted in a private room and, if required, authorized telephone interpreters 
were used. The interviews were audio recorded, transcribed verbatim and translated into English by an authorized translator. The interview transcripts were cross-checked by the first and last authors.

\section{Data analysis}

The principles of thematic analysis described by Braun and Clarke (2006) guided data analysis. Transcripts were read by all authors. The first author developed initial codes line by line and later collated all related codes to form sub-themes. Sub-themes were further organized to develop themes. All the authors met at this stage to review the preliminary themes and sub-themes to reach consensus. Further iterative reviewing and refining was done, resulting in three themes extensively describing the daily life of detainees. NVivo software (QSR International Pty Ltd, 2012) was used to manage the data set.

\section{Results}

The three themes developed, stressors in detention, controlled by the system and forced into passivity, described the stressors experienced by the detainees who likened detention to prison as it created a sense of lack of control, forcing them into passivity.

\section{Stressors in detention}

Threatening behaviour from the authorities, substandard living conditions and absence of a proper support system to cope with stress created a stressful living condition for the detainees.

Suboptimal living conditions. Food provided at the detention centres often triggered complaints for being monotonous, low quality, occasionally low quantity, not their primary choice of food or mainly Arabic diet. However, there were also detainees who said the food served was good enough to prevent starvation.

The conditions in the detention centres were described as disgusting. Hygiene in the toilets and bathrooms was described as poor with occasional absence of essential items such as toilet paper and soap. Some detainees expressed the fear of getting infected with a disease as there were no mechanisms for prevention:

This is not real life, if you want to know how one is living, come here and live here for two nights [...] You [...] go to the toilet and really see the disgusting part of life and when you go to the room [...] one is snoring and another one smells bad. When you put your head on the pillow and want to sleep, it smells disgusting and then you will find out what kind of place this is (Male detainee 2).

Being threatened. The detainees reported feeling threatened by the authorities and by lack of personal safety at the centres. They reported being under constant staff surveillance. They were reportedly threatened to cooperate with the deportation process or to face long-term detention or being handed over to the police in their home countries:

Last time I got a visit from the [police] inspector, she was telling me "If you don't give us your document you will stay here forever [...] or we will hand you over to the authorities in your home country" and the whole conversation was carried out in a very stressful way with shouting (Female detainee 1).

The detainees expressed the fear that reporting mistreatment from the police or the staff might negatively affect their case. If there was a disagreement, such as in the case of choosing a lawyer, detainees said the staff framed them as troublemakers. Irrespective of the constant surveillance and other security measures, the detainees said their personal safety was threatened due to features such as sleeping rooms which cannot be locked. They were also concerned that if there was a fight among detainees, there was a risk that either all the parties involved in the fight would be sent to prison irrespective of who started the fight, or no action would be taken if it was not witnessed by detention staff.

Concerns regarding security varied between centres. For example, all the centres had a pool table except one where pool cues and balls were considered to be a potential security threat. 
Two detention centres allowed the researcher to freely explore the centre and interact with the detainees, while in one a staff member always accompanied the researcher, except during the interviews, as a security measure.

Absence of a proper support system. The absence of a person to freely interact with at the detention centre was described as an important stress factor. Detainees had difficulty in interacting with their families and friends because being detained far away made it time consuming and costly for family and friends to visit while detainees reported having little money to make regular phone calls to their families. Lack of a common language made it difficult for them to interact with fellow detainees. Lack of knowledge of the Swedish language made it challenging for them to communicate with authorities, including the staff at the detention centres. This also created a barrier in understanding legal decisions written in Swedish. The staff were said to merely translate the gist of a multi-page decision which, according to the detainees, was not "complete" information. This incomplete translation was cited as a reason for them having a lack of trust in the staff:

They will just give you papers [to] sign and they read the paper to you. But, what they are reading to you, is it correct? You don't know [...] they ask me to sign [...] I sign [...] sometimes you sign for something you don't know and it is crazy. How can you sign for something that you don't understand? (Male detainee 1).

Detainees talked about instances where interpreters provided by the SMB wrongly translated information affecting detainees' cases negatively. In such instances, they considered it better to communicate directly with the authorities with their limited knowledge of Swedish or English. However, this was not allowed according to the SMB's rules. NGO volunteers visiting the centres often verbally translated the decisions for the detainees. For some detainees, these visits were reportedly helpful in alleviating their anguish.

Television and computers were described as an integral part of their stress management strategy. Other strategies included sleeping, isolating themselves, taking sleeping pills, engaging in physical activities such as playing pool, football or visiting the gym. However, there were detainees who resorted to aggressive methods such as hitting against walls to release their stress.

Language classes, provided at one of the centres were appreciated by the detainees whereas detainees from other centres expressed the wish to have such opportunities so that the time spent in detention could be somewhat useful.

Although the majority of the detainees described detention centres as appalling, they still reasoned it was better to be in detention than being returned to their home countries.

\section{Controlled by the system}

This theme describes how detainees experienced a lack of control over their lives through their interaction with the authorities. They described detention as a prison; sometimes worse than a prison due to the uncertainty created by lack of information.

Require more responsive staff. The general opinion about the detention staff was that "they are not bad, they are not good, they are just doing their job". The detainees appreciated staff members who took time to sit and talk with them. However, when the staff did not fulfil their promises, such as providing toilet paper or getting back to the detainees with an answer from the police or lawyer, they considered this as lack of concern by the staff about their well-being.

According to the detainees, arbitrary restrictions could be avoided to have some control over their lives in detention. For example, one detainee explained that if he missed a meal, he had to wait until the next meal to get food whereas another detainee from the same centre said it was possible to get snacks or sandwiches if requested. Accessibility to amenities such as the gym and courtyard was also at the discretion of the staff.

When the staff used commanding tones such as "you must do it" or forced the detainees to cooperate with deportation, the detainees reported feeling more stressed. Detainees had 
different experiences of detainee-staff interaction. Those who had been detained in more than one centre could tell the differences in staff behaviour and attitude:

There [detention unit X] they are friendly [...] They greet you and say "Hello, I am [name], where do you come from, what problems do you have?" [...] They show they care and they talk in a way so you become calm (Male detainee 4).

Detainees also indicated the lack of proper response from police and lawyers. One detainee reported that his lawyer failed to inform him on time when he had a chance to appeal against the court decision. The information reached him too late and he was detained. Some detainees alleged that police officers working on their cases were dishonest and ignored facts in order to deport them as soon as possible.

Detainees reported having experienced inadequate response from nurses at the centres. Although they have weekly access to nurses at the centres, they reported not being able to alleviate their diseases or not being able to consult a doctor outside the detention centre. If they did get a chance to consult a doctor, often they might have had to wait for several days.

Not knowing the present or the future. For the detainees, life was a question mark. They reported waiting for "The End" but were unsure of what and when "The End" would be. This was said to make it extremely difficult for the detainees to plan their lives for which they reasoned that prisons were better than detention centres because prisoners at least knew the duration of their prison sentence:

I need someone to tell me how long I am gonna sit in here? How long is it gonna take me to get out? That is the only help I need [...] with everything else [...] I have been through worse in my life [...] I just need somebody to tell what is gonna happen and when is it gonna happen (Male detainee 1).

Lack of information was described as a reason for uncertainty. Often the staff did not provide answers or gave reasons such as the case was with the police and they were thus not aware of what was happening. Some detainees reported receiving unclear information which led to misunderstanding. One detainee said he was informed by the police that he would be released from detention once his identity was established. But the police were later said to have contradicted themselves, saying that he could not be released with or without his identity being established, leaving the detainee uncertain about his chances of being released.

Uncertainty was said to increase stress levels and sleeplessness. Life became miserable as the duration of detention got longer; however, longer duration was reportedly manageable as long as they knew the exact duration.

Prison with some "extra flavour". Placing the detainees in prison while being transported to detention centres had an impact on them; but it was the restrictions imposed on them in detention, lack of freedom and authorities' exercising of control, that made them feel imprisoned. They described detention centres as prisons with some "extra flavours" such as a pool table, telephone and internet:

$[\ldots]$ here, it is just [a] prison [...] they are just doing something to make it [...] to [...] give you some nice flavour like detention [...] but it is prison [...] (Male detainee 1).

Some detainees who had been incarcerated earlier said prisons were better because there was a routine to sleep, wake up, eat and perform other daily activities. According to them, this routine made prison life appear closer to normality. One detainee, an ex-prisoner, reportedly exhibited violent behaviour in an attempt to be sent back to prison.

\section{Forced into passivity}

With all the controls and stresses described above, the detainees realised it was futile to seek help. Legal and administrative reasons given for detention and deportation were considered unfair with some detainees arguing that they had complied with all the instructions from the SMB and had never tried to hide. Yet, they were detained and therefore believed nothing could change 
their situation resulting them becoming passive. According to them, the people who could help them, the SMB, the police and the lawyers, were focused on deporting them:

They [SMB and police] are supposed to help you but I don't think you can count on immigration and the police to help you [...] I think [...] they have a job to do and their job is to deport you [...] as soon as possible (Male detainee 8).

The detainees reported feeling powerless to influence their life situation when their requests were denied. They considered the lawyers to be ineffective and loyal to the SMB who pay for their services. They also expressed the feeling that the SMB and the police have double standards. One detainee, for example, said he could not understand why he was detained while his friends in a similar situation were not. The detainees considered EU policies to be fallacious. A "free and fair trial" for everyone, as stated by the EU, was denied to the detainees. As they see it, detention invalidates freedom and therefore the "free" aspect of the "free and fair trial". They believed the authorities did what they wanted to do irrespective of the detainees' situation or the law, thus making it futile to seek help.

In light of the above experiences, the detainees realized and resigned themselves to the reality that it was futile to seek help:

I have explained [...] my situation [...] they [SMB] disappoint me and I say now, this is my reality, this is my life (Male detainee 7).

\section{Discussion}

The detainees described their experiences of detention as imprisonment because they, like prisoners, lacked control and consequently found it futile to seek help.

\section{Imprisonment and lack of control}

The main difference between prisons and detention is that imprisonment is a penal measure designed to punish criminals whereas immigration detention is designed as an administrative measure to enforce deportation (Broeders, 2010; Khosravi, 2009). However, our results indicate that the detainees considered detention to be imprisonment. Furthermore, there are similarities between experiences of imprisonment among prisoners and the experience of detention among the detainees. Deprivation of liberty in immigration detention is similar to that in prison; this is the main reason why detainees compared detention centres to prison and considered it as a punishment (David Scott, 2008; Khosravi, 2009; Klein and Williams, 2012; Leerkes and Broeders, 2010; Coffey et al., 2010). Confinement, combined with the irregular sleeping patterns and constant stress found in prisons (Dirkzwager and Kruttschnitt, 2012; Johnsen et al., 2011; Kruttschnitt et al., 2000), echoes with the experiences described by the participants in this study and may have contributed to their reasons to compare detention centres to prisons (Silove et al., 2007). At times, detention can be an experience worse than prison as detainees are deported to countries from which they were forced to flee, whereas prisoners are released back to their home community (Klein and Williams, 2012).

Confinement epitomizes control and limits the actual control for those who are confined (Woodall et al., 2014; Goodstein et al., 1984). Detainees perceived lack of control over their own lives and overwhelming control by the state (SMB) on their life situation. Lack of control over their own life situation was experienced through the inadequate responses from the authorities, creating a lack of information and increasing the conviction of futility in seeking help. They also experienced this through their inability to get a doctor's consultation, their inability to change the monotony of meals, or while not getting a positive response after doing all they could. The state's control over the detainees' lives was mainly felt through confinement itself and through various additional restrictions in detention such as the time restriction to access the courtyard. As per the guidelines issued by the Swedish Migration Board (2010), the staff working at the centres are supposed to provide detainees with information about their situation so that detainees can take responsibility for the situation. Khosravi (2009) refers to this as illusory sense of power, an observation which resonates with our results where detainees reported not receiving proper information and experiencing a lack of control. Although detainees might be able to predict their daily schedule in 
detention, such as the meal serving schedule or visiting times with great accuracy, they are uncertain about events which are most consequential to their lives; namely, the outcome of their detention case. Lack of information pertaining to important events in one's life can lead to a sense of lack of control (Goodstein et al., 1984). According to the Ottawa Charter for Health Promotion (WHO, 1986), the capacity of individuals to assume control over their lives is a prerequisite for good health. Having a low sense of control makes it easier to feel helplessness (Skinner, 1996; Abramson et al., 1978), experience higher levels of stress (Krause and Stryker, 1984) and leads to more frequent illness episodes (Seeman and Seeman, 1983).

As indicated earlier, detainees are known to have mental and physical illness (Coffey et al., 2010; Keller et al., 2003; Pourgourides, 1997; Silove et al., 2007; PHR and The Bellevue/NYU Program for Survivors of Torture, 2003; Steel et al., 2004; Robjant et al., 2009; SMB, 2012; Venters et al., 2009). This indicates the need for increased availability and accessibility of health care services in detention centres (Hollings et al., 2012; PHR and The Bellevue/NYU Program for Survivors of Torture, 2003; Silove et al., 2007; Venters et al., 2009). In Swedish detention centres, there is a lack of health care services, especially mental health care services. This is of concern considering the confined living space, stressful situation and denied requests for hospital appointments by the detainees. A recent record-based study conducted in Sweden (Lindgren et al. , 2012) concluded that asylum seekers (majority of the detainees in Sweden are rejected asylum seekers) reported more symptoms of mental illness compared to any other group of immigrants. A lack of health care services was highlighted in the most recent European Committee for the Prevention of Torture and Inhuman or Degrading Treatment or Punishment (CPT) 2009 report and one of its recommendations was to ensure appropriate psychological and psychiatric assistance for the detainees.

In light of our results, and recommendations from the UNHCR (2012) and considering the trauma the detainees might have been through (Lindgren et al., 2012; Steel et al., 2011), it is critical to improve the health care services at the detention centres.

\section{Staff-detainee interaction}

Staff behaviour can make the experience of confinement either bearable or unbearable (Stevens, 1998; Dirkzwager and Kruttschnitt, 2012; Johnsen et al., 2011). Similar to the experiences of prisoners (Kruttschnitt et al. , 2000; Stevens, 1998; Venters et al., 2009; David Scott, 2008; Steel et al., 2004; Goodstein et al., 1984), a lack of response and false promises from the staff reinforced the detainees' conviction that seeking help is futile, which led to a feeling of lack of control and passivity. However, examples such as one detainee succeeding in getting snacks between meals while others fail indicate that with good staff-detainee interaction detainees can attain a sense of control and positively influence their health and well-being in detention.

Not only the level of interaction but also the type of interaction affects the well-being of detainees (Robjant et al., 2009; Steel et al., 2004; Hall, 2010). Correctional officers who exhibited confrontational characteristics in prisons made prisoners uneasy (Dirkzwager and Kruttschnitt, 2012), mirroring our study participants' experiences where they reported feeling more stressed when the staff or the police exhibited threatening behaviour or used commanding tones.

\section{Scope for change?}

Compared to other major host countries, the use of detention is limited in Sweden and prisons are not used for detention (Malloch and Stanley, 2005; Venters et al., 2009; Hall, 2010; Sampson et al., 2011). The CPT (2009) report considered Swedish detention centres to have satisfactory standards with the exception of health care provisions. Studies from other countries have shown factors, such as the presence of uniformed personnel, the use of prisons for detention, high walls, sleeping rooms without windows, the use of cameras to monitor the detainees, the need for detainees to wear uniforms, all make them feel treated as prisoners (Hollings et al., 2012; Malloch and Stanley, 2005; Silove et al., 2007; Coffey et al., 2010; PHR and The Bellevue/NYU Program for Survivors of Torture, 2003). Although most of these factors are absent in the Swedish detention centres, our participants still reported feeling of being imprisoned. This finding seems to indicate that detention systems around the world have similar effects on detainees irrespective of 
the structural and administrative variations. Guidelines from international organizations (Mendonça, 2010; IOM, 2011; UNHCR, 2012) usually recommend avoidance of prisons or facilities which resemble prison settings for immigration detention. However, our results suggest that the penal nature of detention, dubbed as "administrative" by the authorities, staff behaviour and arbitrary restrictions in detention contribute largely to the feeling of being imprisoned, thus creating a sense of lack of control. This issue needs to be better addressed in guidelines.

Although it might be impossible to attain a full sense of control in detention, it is possible to improve the sense of experienced control without altering the actual conditions through cognitive techniques such as preventing the perception of lack of control, maintaining optimism (Skinner, 1996) or by engaging in activities such as painting or reading which might provide a provisional escape from the institutional life (Woodall et al., 2014). As indicated in the results, differences in administrative practices among various centres in terms of security, staff behaviour and other available amenities such as educational activities, had an impact on detainees. A less restrictive environment within the centres had a positive impact on the detainees by granting them more freedom and control. Correctional officers' understanding and willingness to stretch some relatively insignificant rules, such as the hours allotted for being in the courtyard, had a positive impact on the prisoners' quality of life and well-being (Dirkzwager and Kruttschnitt, 2012; Kruttschnitt et al., 2000; Johnsen et al., 2011).

These examples indicate that even within the existing structural and legal framework, staff-detainee interaction could be improved, and arbitrary use of power could be avoided, giving greater control to detainees. This would increase their sense of control, reduce the feeling of imprisonment, and thus mitigating the effects of detention on the health and well-being of the detainees.

\section{Methodological considerations}

Although the participants were informed that their participation would not influence their case, the possibility of information being exaggerated by the detainees cannot be ignored considering their strong desire to get help to be released. However, similar results from other studies and reflections from the project reference group seem to support the study results. A recently concluded project by the SMB (2012) in one of the detention centres also drew similar conclusions, especially regarding the restriction on courtyard access and the provision of health care at the detention centre. We might have missed recruiting extreme cases, highly stressed or passive detainees, if they were not seen in the common areas. Although it would have been interesting to explore their experiences, we decided not to intrude upon their privacy by knocking on the doors of their sleeping rooms. The study described shows only one side of the picture. Other stakeholder perspectives, such as those of the staff and health care providers should be studied to better understand the detention system and to create a supportive environment for the detainees.

\section{Conclusion}

Alternatives to detention must always be pursued before resorting to immigration detention. However, if states deem detention to be necessary, it is important that the health and well-being of migrants in detention is not ignored. Immigrant detainees in Sweden experience detention as imprisonment and experience a lack of control over their life situation negatively affecting their health and well-being. In order to mitigate the effects of detention on detainees' health and well-being, health care provision at the detention centres should be improved, arbitrary restrictions in detention should be avoided and staff-detainee interaction should be improved.

\section{Acknowledgments}

The authors thank all the participants for sharing their stories during a difficult period in their life. The authors are most thankful to Niclas Axelsson from the Swedish Migration Board for providing with valuable insights into the detention management system. The authors thank Mikael J. Zaar

\begin{tabular}{l|l|l} 
PAGE 82 & INTERNATIONAL JOURNAL OF MIGRATION, HEALTH AND SOCIAL CARE & VOL. 11 NO. 22015
\end{tabular} 
from the Swedish Migration Board for his contributions during the initial stages of the study. The authors are grateful to Caritas Sweden and Red Cross Sweden for their valuable feedback on the results. The study was co-financed by the European Refugee Fund (ERF).

Competing interests: the authors declare they have no competing interests.

Authors' contributions: Soorej Jose Puthoopparambil and Magdalena Bjerneld designed and organized the study. Soorej Jose Puthoopparambil collected and analysed the data and drafted the manuscript. Magdalena Bjerneld and Beth Maina Ahlberg took part in the data analysis and drafting and writing the manuscript. All authors have read and approved the final manuscript.

\section{References}

Abramson, L.Y., Seligman, M.E. and Teasdale, J.D. (1978), "Learned helplessness in humans: critique and reformulation", Journal of Abnormal Psychology, Vol. 87 No. 1, pp. 49-74.

Awofeso, N. (2005), "Re-defining 'health'”: WHO”, available at: www.who.int/bulletin/bulletin_board/83/ ustun11051/en/ (accessed 6 June 2014).

Braun, V. and Clarke, V. (2006), "Using thematic analysis in psychology", Qualitative Research in Psychology, Vol. 3 No. 2, pp. 77-101.

Broeders, D. (2010), "Return to sender?: administrative detention of irregular migrants in Germany and The Netherlands", Punishment and Society, Vol. 12 No. 2, pp. 169-86.

Callahan, D. (1973), “The WHO definition of “health'”, The Hastings Center Studies, Vol. 1 No. 3, pp. 77-87.

Coffey, G.J., Kaplan, I., Sampson, R.C. and Tucci, M.M. (2010), "The meaning and mental health consequences of long-term immigration detention for people seeking asylum”, Social Science \& Medicine, Vol. 70 No. 12, pp. 2070-9.

David Scott, D. (2008), “Thinking about detention”, Criminal Justice Matters, Vol. 71 No. 1, pp. 11-13.

Dirkzwager, A.J.E. and Kruttschnitt, C. (2012), 'Prisoners' perceptions of correctional officers' behavior in English and Dutch prisons", Journal of Criminal Justice, Vol. 40 No. 5, pp. 404-12.

European Committee for the Prevention of Torture and Inhuman or Degrading Treatment or Punishment (CPT) (2009), "Report to the Swedish Government on the visit to Sweden carried out by the European Committee for the Prevention of Torture and Inhuman or Degrading Treatment or Punishment (CPT) from 9 to 18 June 2009", available at: www.cpt.coe.int/documents/swe/2009-34-inf-eng.pdf (accessed 29 May 2014).

Fazel, M. and Silove, D. (2006), “Detention of refugees”, BMJ, Vol. 332 No. 7536, pp. 251-2.

Fekete, L. (2005), "The deportation machine: Europe, asylum and human rights", Race \& Class, Vol. 47 No. 1, pp. 64-78.

Goodstein, L., MacKenzie, D.L. and Shotland, R.L. (1984), "Personal control and inmate adjustment to prison", Criminology, Vol. 22 No. 3, pp. 343-69.

Hall, A. (2010), “These people could be anyone': fear, contempt (and empathy) in a British immigration removal centre", Journal of Ethnic and Migration Studies, Vol. 36 No. 6, pp. 881-98.

Hollings, J., Samuilova, M. and Petrova-Benedict, R. (2012), "Health, migration and border management: analysis and capacity-building at Europe's borders", International Journal of Public Health, Vol. 57 No. 2, pp. 363-9.

Huber, M., Knottnerus, A.J., Green, L., van der Horst, H.R., Jadad, A., Kromhout, D., Leonard, B., Lorig, K., Loureiro, M.I., van der Meer, J.W.M., Schnabel, P., Smith, R., van Weel, C. and Smid, H. (2011), "How should we define health?", BMJ, Vol. 343:d4163, available at: www.bmj.com/content/343/bmj.d4163.full.pdf+html

International Organization for Migration (IOM) (2011), "International standards on immigration detention and non-custodial measures", available at: www.iom.int/files/live/sites/iom/files/What-We-Do/docs/ IML-Information-Note-Immigration-Detention-and-Non-custodial-Measures.pdf (accessed 23 April 2014).

Johnsen, B., Granheim, P.K. and Helgesen, J. (2011), "Exceptional prison conditions and the quality of prison life: prison size and prison culture in Norwegian closed prisons", European Journal of Criminology, Vol. 8 No. 6, pp. 515-29.

Keller, A.S., Rosenfeld, B., Trinh-Shevrin, C., Meserve, C., Sachs, E., Leviss, J.A., Singer, E., Smith, H., Wilkinson, J., Kim, G., Allden, K. and Ford, D. (2003), "Mental health of detained asylum seekers", The Lancet, Vol. 362 No. 9397, pp. 1721-3. 
Khosravi, S. (2009), "Sweden: detention and deportation of asylum seekers", Race \& Class, Vol. 50 No. 4, pp. 38-56.

Klein, A. and Williams, L. (2012), "Immigration detention in the community: research on the experiences of migrants released from detention centres in the UK", Population, Space and Place, Vol. 18 No. 6, pp. 741-53.

Krause, N. and Stryker, S. (1984), "Stress and well-being: the buffering role of locus of control beliefs", Social Science \& Medicine, Vol. 18 No. 9, pp. 783-90.

Kruttschnitt, C., Gartner, R. and Miller, A.M.Y. (2000), "Doing her own time? Women's responses to prison in the context of the old and the new penology", Criminology, Vol. 38 No. 3, pp. 681-718.

Lachman, M.E. and Weaver, S.L. (1998), "The sense of control as a moderator of social class differences in health and well-being”, Journal of Personality and Social Psychology, Vol. 74 No. 3, pp. 763-73.

Leerkes, A. and Broeders, D. (2010), "A case of mixed motives?: formal and informal functions of administrative immigration detention", British Journal of Criminology, Vol. 50 No. 5, pp. 830-50.

Lindgren, J., Ekblad, S., Asplund, M., Irestig, R. and Burström, B. (2012), "Mental ill health among asylum seekers and other immigrants in Sweden", International Journal of Migration, Health and Social Care, Vol. 8 No. 4, pp. 167-79.

Malloch, M.S. and Stanley, E. (2005), "The detention of asylum seekers in the UK: representing risk, managing the dangerous", Punishment \& Society, Vol. 7 No. 1, pp. 53-71.

Mendonça, A.C. (2010), "Resolution 1707 (2010): the detention of asylum seekers and irregular migrants in Europe”, available at: http://assembly.coe.int/ASP/Doc/XrefViewPDF.asp?FileID =12435\&Language $=$ EN (accessed 26 May 2014).

Ministry of Justice (2005), "Aliens Act (Utlänningslag) (2005:716)", Justitiedepartementet, Stockholm.

Ministry of Justice (2008), "Lag (2008:344) om hälso- och sjukvård åt asylsökande m.fl.", Justitiedepartementet, Stockholm.

PHR and The Bellevue/NYU Program for Survivors of Torture (2003), "From persecution to prison: the health consequences of detention for asylum seekers", available at: www.survivorsoftorture.org/files/pdf/ perstoprison2003.pdf (accessed 17 February 2014).

Pourgourides, C. (1997), "A second exile: the mental health implications of detention of asylum seekers in the UK”, Psychiatric Bulletin, Vol. 21 No. 11, pp. 673-4.

QSR International Pty Ltd (2012), NVivo Qualitative Data Analysis Software, Version 10 ed., QSR International Pty Ltd, Melbourne.

Robjant, K., Hassan, R. and Katona, C. (2009), "Mental health implications of detaining asylum seekers: systematic review", The British Journal of Psychiatry, Vol. 194 No. 4, pp. 306-12.

Sampson, R., Mitchell, G. and Bowring, L. (2011), "There are alternatives: a handbook for preventing unnecessary immigration detention”, available at: www.ohchr.org/Documents/Issues/Migration/Events/IDC. pdf (accessed 15 February 2014).

Saracci, R. (1997), "The world health organisation needs to reconsider its definition of health", BMJ (Clinical Research ed.), Vol. 314 No. 7091, pp. 1409-10.

Seeman, M. and Seeman, T.E. (1983), "Health behavior and personal autonomy: a longitudinal study of the sense of control in illness", Journal of Health and Social Behavior, Vol. 24 No. 2, pp. 144-60.

Silove, D., Austin, P. and Steel, Z. (2007), "No refuge from terror: the impact of detention on the mental health of trauma-affected refugees seeking asylum in Australia", Transcultural Psychiatry, Vol. 44 No. 3, pp. 359-93.

Silverman, S.J. and Massa, E. (2012), "Why immigration detention is unique", Population, Space and Place, Vol. 18 No. 6, pp. 677-86.

Skinner, E.A. (1996), "A guide to constructs of control”, Journal of Personality and Social Psychology, Vol. 71 No. 3, pp. 549-70.

Steel, Z., Liddell, B.J., Bateman-Steel, C.R. and Zwi, A.B. (2011), "Global protection and the health impact of migration interception”, PLOS Medicine, Vol. 8 No. 6, available at: http://journals.plos.org/plosmedicine/ article?id=10.1371/journal.pmed. 1001038

Steel, Z., Momartin, S., Bateman, C., Hafshejani, A., Silove, D.M., Everson, N., Roy, K., Dudley, M., Newman, L., Blick, B. and Mares, S. (2004), "Psychiatric status of asylum seeker families held for a protracted period in a remote detention centre in Australia", Australian and New Zealand Journal of Public Health, Vol. 28 No. 6, pp. 527-36. 
Stevens, D.J. (1998), "The impact of time-served and regime on prisoners' anticipation of crime: female prisonisation effects”, The Howard Journal of Criminal Justice, Vol. 37 No. 2, pp. 188-205.

Swedish Migration Board (2006), 602805 Faktablad om förvar och uppsikt. Engelsk översättning, Informationsenheten, Migrationsverket, Norrköping.

Swedish Migration Board (2010), Divisional Head's instruction on common policies and procedures at the Swedish Migration Board detention centers Nerksamhetschefens instruktion om gemensamma riktlinjer och rutiner vid Migrationsverkets förvarsenheter), Swedish Migration Board, Norrköping.

Swedish Migration Board (SMB) (2012), Att vara kvinna \& sitta i förvar - en kartläggning av behov \& förslag på insatser för förvarstagna kvinnor, Swedish Migration Board, Norrköping.

Swedish Migration Board (2013), "Asylum decisions, 2012”, available at: www.migrationsverket. se/download/18.43648b4513b902d42692f5c/Avgjorda+asyl\%C3\%A4renden+2012+-+Asylum+decisions+ 2012.pdf (accessed 16 February 2014).

Swedish Migration Board (2014), "Årsredovisning 2013 (Annual report 2013)", available at: www. migrationsverket.se/download/18.7c00d8e6143101d166d29f5/1393235256561/\%C3\%85rsredovisning+ 2013.pdf (accessed 11 March 2014).

UNHCR (2012), "Detention guidelines: guidelines on the applicable criteria and standards relating to the detention of asylum-seekers and alternatives to detention", available at: www.unhcr.org/refworld/docid/ 503489533b8.html (accessed 18 December 2013).

UNHCR (2014), "Asylum trends 2013: levels and trends in industrialized countries", available at: www.unhcr. org/5329b15a9.html (accessed 22 March 2014).

Venters, H., Dasch-Goldberg, D., Rasmussen, A. and Keller, A.S. (2009), "Into the abyss: mortality and morbidity among detained immigrants", Human Rights Quarterly, Vol. 31 No. 2, pp. 474-95.

Wallston, K., Wallston, B., Smith, S. and Dobbins, C. (1987), "Perceived control and health", Current Psychology, Vol. 6 No. 1, pp. 5-25.

WHO (1946), "Constitution of the World Health Organization", available at: www.who.int/governance/eb/ who_constitution_en.pdf (accessed 15 August 2014).

WHO (1986), The Ottawa Charter for Health Promotion, WHO, Ottawa.

Woodall, J., Dixey, R. and South, J. (2014), "Control and choice in English prisons: developing healthpromoting prisons", Health Promotion International, Vol. 29 No. 3, pp. 474-82.

\section{About the authors}

Soorej Jose Puthoopparambil is a Doctoral Student in International Health at the Department of Women's and Children's Health, Uppsala University. He has a master's degree in international health and has been involved with national and international projects aimed at improving immigrant health. Soorej Jose Puthoopparambil is the corresponding author and can be contacted at: soorej.jose@kbh.uu.se

Beth Maina Ahlberg is an Adjunct Professor of International Health with Sociology background and the Head of Research at the Skaraborg Institute for Research and Development. She has extensive experience in research in countries in Eastern and Southern Africa and in Sweden. Her particular focus has been on methodological issues in the study of sexual and reproductive health, gender issues as well as migration and health.

Magdalena Bjerneld, Nurse Tutor, MSc, PhD, is a Researcher and University Teacher with Excellent Teacher Award at the Department of Women's and Children's Health, Uppsala University. Her field of expertise is public health in humanitarian assistance and migration.

For instructions on how to order reprints of this article, please visit our website:

www.emeraldgrouppublishing.com/licensing/reprints.htm

Or contact us for further details: permissions@emeraldinsight.com 